\title{
Global Challenges, the Economist, and the Common Good
}

J. Tirole

2014 Nobel Prize winner

Toulouse School of Economics

Toulouse, France

\begin{abstract}
This lecture was delivered in November 2018 at Financial University in Moscow, Russia, to the faculty and students. Using some current policy debates as illustrations, it describes the social scientist's mission, and how economics can deliver the common good.
\end{abstract}

Keywords: common good; social responsibility; regulation and competition policy; climate change; incentives

For citation: Tirole J. Global challenges, the economist, and the common good. Finansy: teoriya i praktika = Finance: Theory and Practice. 2019;23(1):6-12. DOI: 10.26794/2587-5671-2019-23-1-6-12

\section{Глобальные задачи, профессия экономиста и общее благо}

\author{
Ж. Тироль, \\ лауреат Нобелевской премии 2014 г., \\ Тулузская школа экономики, \\ Тулуза, Франция
}

\begin{abstract}
АННОТАЦИЯ
Эта лекция была прочитана в ноябре 2018 г. в Финансовом университете в Москве, Россия, для преподавателей и студентов. Используя некоторые текущие политические дебаты в качестве иллюстрации, автор описывает миссию социолога и то, как экономика может принести общее благо.

Ключевые слова: общее благо; теории регулирования и конкурентной политики; изменение климата; стимулы; платежные системы; корпоративные финансы
\end{abstract}

Для иитирования: Tirole J. Global challenges, the economist, and the common good. Финансы: теория и практика. 2019;23(1):6-12. DOI: 10.26794/2587-5671-2019-23-1-6-12

\section{INTRODUCTION}

My recent book Economics for the Common Good" ${ }^{1}$ develops a vision of economics as a moral and philosophical science. While covering specific policy topics such as the digital revolution, the financial crisis, deregulation, antitrust, or climate change, it describes how economics has evolved over the years to become both more relevant to address the key challenges of our time and more open to other disciplines in human and social sciences. Chapter III, titled "The economist in civil

${ }^{1}$ Tirole Jean. Économie du bien commun. 2016. Paris, France: Presses Universitaires de France. 672 p. Available also in English: Tirole Jean. Economics for the Common Good. Princeton, NJ: Princeton University Press. 576 p. society", discusses what it means to be an economist, and will be my starting point in the lecture ${ }^{2}$.

This book, accessible to any intellectually curious reader with little or no previous knowledge of economics, aims at showing how economics can open a window on the world, and contribute to our wellbeing. To this purpose, it explains how economics can help us understand the world and guide policy.

\footnotetext{
${ }^{2}$ See also Bénassy-Quéré Agnès, Blanchard Olivier Jean, Tirole Jean. What role for economists in policy-making? Conseil d'analyse économique. Notes du conseil d'analyse économique. 2017/6;(42):1-12. This document is the English version of: Agnès Bénassy-Quéré et al. Les économistes dans la cité, Notes du conseil d'analyse économique. 2017/6;(42):1-12. Available online at: https://www.cairn-int.info/article-E_NCAE_042_0001-whatrole-for-economists-in.htm.
} 
More broadly, it argues that social scientists need to engage with the many challenges our society is facing, to help identify our key objectives and the tools needed to meet them.

The ambition of the economics for the common good is, in short, to help build institutions that will work in the general interest. There are many situations when citizens', companies', states' and countries' objectives diverge from the general interest. So, I, as a consumer, may emit too much carbon dioxide, I may not protect the environment, I may drive too fast, I may overconsume antibiotics, I may fail to vaccinate my children... Every time I do so, I do not take into account the effect that my actions will have on other people. Similarly, a business or a bank may take undue risk and jeopardise the jobs of their employees and the money of their investors or, maybe, taxpayers as well. They may also abuse their market power. The state may accumulate too much public debt and unfunded pension liabilities, provide poor education, tolerate inequality, maybe create a financial crisis through poor prudential supervision. And, of course, when it comes to countries, national interest always comes first, often to the detriment of global welfare; this issue is particularly problematic in these times of acute nationalism and distrust of multilateralism. Today, we see broad indifference to global warming, trade wars, fiscal competition and other dysfunctionings of the world order.

What is the common feature in all these examples? It is that the individual interest trumps the general (common) interest. Incentives of actors (citizens, firms, government, countries) are inadequate. They are not in line with the common good. [I will come later to the definition of the common good.]

What can we do? The first thing we can do is to try to persuade citizens, firms, states, countries to behave better and take into account not only their own interests but also the general interest. This is what corporate social responsibility ${ }^{3}$ and individual social responsibility attempt to do: persuade people to behave better. Sociologists and social psychologists emphasise (what they call) norm-based interventions, namely campaigns and messages that seek to alter people's perceptions of what constitutes "normal" behaviour or values among their peers ${ }^{4}$.

\footnotetext{
${ }^{3}$ For example, see my paper co-written with Roland Bénabou "Individual and corporate social responsibility", Economica, 77:1-19 (2010).

${ }^{4}$ Bénabou Roland, Tirole Jean. Laws and Norms. NBER Working Paper Series. Working Paper 17579; 2011. http://www. nber.org/papers/w17579. In this paper we analyzed how private decisions and public policies are shaped by personal and
}

Norm-based interventions here are really about trying to change the social norm so that it becomes shameful to be selfish.

The second way of dealing with selfish behaviors is to provide incentives through taxation or the legal system. Sometimes one can combine persuasion and incentives. For example, in southern Europe, many people used to smoke in restaurants and other public places. That misbehavior quickly disappeared. There was a prohibition, but at the same time a campaign to persuade people that smoking in public places was selfish. People stopped smoking in front of others even in circumstances where the law obviously could not be enforced.

However, there are limits to persuasion. Take climate change for example. The Rio summit in 1992 unveiled some agreement, not as solid as now but an agreement nonetheless, that climate change was a big threat to humanity. Since then, governments around the world have provided their citizens and companies with little monetary incentive to reduce their carbon emissions. Rather, authorities have tried to persuade economic agents to change their behaviors, to be greener. And the latter have not complied. The $5^{\text {th }}$ Report of the IPCC (The Intergovernmental Panel on Climate Change - ed.) $)^{5}$ estimates that, following the current trend, the average temperature would increase by somewhere between $2.5^{\circ} \mathrm{C}$ and $7.8^{\circ} \mathrm{C}$ by the end of this century, after having already increased by almost $1{ }^{\circ} \mathrm{C}$ over the last century ${ }^{6}$.

For an economist, the adequate incentive consists in confronting economic agents with a carbon price

societal preferences ("values"), material or other explicit incentives ("laws") and social sanctions or rewards ("norms").

${ }^{5}$ IPCC, 2014: Climate Change 2014: Synthesis Report. Contribution of Working Groups I, II and III to the Fifth Assessment Report of the Intergovernmental Panel on Climate Change [Core Writing Team, R.K. Pachauri and L.A. Meyer (eds.)]. IPCC, Geneva, Switzerland, 151 p. https://www.ipcc. ch/report/ar5/syr/. See also OECD (2018), Effective Carbon Rates 2018: Pricing Carbon Emissions through Taxes and Emissions Trading, OECD Publishing, Paris, https://doi. org/10.1787/9789264305304-en. The report presents new data on taxes and tradeable permits for carbon emissions in 42 OECD and G20 countries accounting for around $80 \%$ of global emissions. It finds that today's carbon prices - while slowly rising - are still too low to have a significant impact on curbing climate change. The report shows that the carbon pricing gap - which compares actual carbon prices and real climate costs, estimated at $30 € / \mathrm{tCO} 2$ - was $76.5 \%$ in 2018 . http:// www.oecd.org/ctp/tax-policy/few-countries-are-pricing-carbon-high-enough-to-meet-climate-targets.htm.

${ }^{6}$ Gollier Christian, Tirole Jean. Negotiating effective institutions against climate change (2015) Economics of Energy and Environmental Policy, 4(2):5-27. 
for their emissions, either a carbon tax or through a carbon cap-and-trade mechanism (tradable emission permits, with authorities fixing a cap on possible emissions). Such carbon price incentivises individuals, companies and administrations to emit less carbon. However, as I pointed out, very few countries have imposed such a carbon price, or when they did so, they did it at such a low level that little was done to protect the environment- the only two exceptions being Switzerland and Sweden. In Europe, the emissions trading system was initially ambitious (as least in comparison with policies adopted in other regions of the world). However permits' prices fell drastically due to several factors - recession, investment in renewables... - and the absence of any countervailing reduction in the supply of permits. The carbon price went down from a peak of $30 € / \mathrm{tCO}_{2}$ to around $5-7 € / \mathrm{tCO}_{2}$ today. There is so much one can do by only trying to persuade; we also need to add real incentives to change the individual interest and put the general interest back to the centre.

\section{WHAT IS THE COMMON GOOD?}

Each of us has a different position in society; we have different jobs, different dialects and cultures, different tastes, different genders, races and ethnicities, different experiences. How do we then define the common good? The best we have for this is a thought experiment called "the veil of ignorance". This thought experiment thinks in terms of a social contract, and has a long philosophical tradition. It goes back to England in the $17^{\text {th }}$ century, with Thomas Hobbs and John Locke, to continental Europe in the $18^{\text {th }}$ century with Immanuel Kant and Jean Jacques Rousseau, and also to the US in the $20^{\text {th }}$ century, with scholars such as John Rawls and John Harsanyi.

This thought experiment captures a very simple idea. Imagine you are not born yet. Because you are not born yet, you do not know what your place in society will be. You will be born in a rich family or a poor family, in a learned family or not. You will be born in Russia, France or India. You will be religious or agnostic. You will have good genes and resulting health, or not. You will be characterized by various other traits, such as ethnicity, race, gender, sexual preferences, and so on. But you do not know yet which will prevail.

So, just imagine that you are not born yet (you are behind the veil of ignorance) and ask yourself a simple question: what kind of society would I like to live in?

Now, let me qualify this a little bit. I do not have in mind a La-La land, a world where everybody would spontaneously act for the common good. A La-La land sounds nice for children, but we do not live in that world: we must consider incentives. Russians experienced the consequences of the "myth of the new man" in Soviet Union times: A man different from existing ones, selfless, full of self-control, hardworking, devoted to society, putting the interests of others before, not behind, his self-interest.

Now, some might say that the Soviet Union and other regimes, like Eastern Germany, Maoist China, and North Korea still today, failed because they had the wrong leaders. That is not the issue. The conception of society was incorrect. Relying on a hypothetical "new man" eventually leads to a totalitarian regime. Citizens don't behave as planned, and they then have to be constrained. Which leads to such things as the deprivation of freedom as well as economic misery. Whether a student, a professor, an employee, a politician, a CEO, an NGO worker, whatever - we all react to incentives.

Even this very simple thought experiment already delivers a number of implications. For example, the imperative of offering equal opportunity to citizens. Just think of it as of insurance behind the veil of ignorance. You do not know where you are going to be, in which family you will be born. And you would like to enjoy a good education, a right which, by the way, is unfortunately often violated: more and more, education is akin to an insider trading system in many countries; people who have money and who are informed of the right subjects and channels send their children to the good schools, and others do not. Gender equality is similarly a no-brainer if one considers the thought experiment in which one does not know whether one will be a woman or a man. The desirability of religious, ethnic, and many other forms of tolerance also results from the veil-of-ignorance thought experiment.

Same thing with the access to good medical care (universal health care); it is not our fault if we develop cancer; and so we must be insured against the cost of treatments. Now, the market may well go against that; especially with genetics and artificial intelligence: algorithms which predict our future health accurately, will select out bad risks for insurance purposes. If you are endowed with a "good health capital", you will get very good and cheap health insurance, but if you are known to develop cancer in the future, then you will pay extremely high prices for health insurance, and that is unfair.

Behind the veil of ignorance, we also do not want to have monopolies that raise price, offer low quality services and do not innovate; we do not want to 
have corruption and so on. So, even with this very simple thought experiment, we can go pretty far on how society should be organized.

It is our job as economists to deliver tools that will promote the common good at a reasonable cost. I would like to argue that this requires a long-term vision. By contrast, politicians often take a shortterm vision. I am not necessarily blaming politicians. Like all of us, they react to their incentives, which may well coincide with being elected and staying in power. Even if they are decent and honest people, they tend to favor the short term over the long term because they want to be re-elected or stay in power. We, social scientists, face no such constraint and must take a long-term view.

\section{DELIVERING THE COMMON GOOD}

Next, how does one deliver economics for the common good? The answer is in the following triptych: market-state-social responsibility. The first tool is the market, an efficient method of allocating scarce resources as long as it is competitive. Especially in comparison with public ownership of production means. Continued state ownership ${ }^{7}$ indeed may not be a good thing, for several reasons. The first is the existence of an implicit state guarantee. A state-owned bank or enterprise faces lower incentive to make itself sustainable, as the state's implicit guarantee will allow it to refinance even under lackluster performance. Second, the implicit guarantee destroys the level playing field with the private sector, which does not have access to such backstops. Third, there may be some pressure on the firms and banks under state control to pursue specific political goals.

But there are also lots of market failures. Indeed, researchers in economics deal mostly with market failures. Which market failures? First, market power, the ability of large firms to raise prices, to lower quality, and to fail to innovate. Large firms do not innovate because they do not want to cannibalise their own products.

But there are many other markets failures: markets may be marred by incomplete or asymmetric information. A depositor does not know whether her bank has sound balance-sheet and off-balancesheet positions, and therefore does not have the information required to assess whether her deposits are safe. Similarly, the purchaser of food in a shop

\footnotetext{
${ }^{7}$ Transient state ownership may be fine, as shown by the creation of bad banks in reaction to the banking crisis in Scandinavia in the early 90's.
}

or a restaurant patron has no way of investigating the food chain behind what he is going to eat. A patient cannot know about the therapeutic or addictive properties of a molecule (see e.g. the recent opioid crisis). Etc. This is why we have consumer protection agencies.

There may be externalities (I reduce the welfare of others when I emit carbon, fail to vaccinate my children, overconsume antibiotics, etc). When I use my car, I pollute the environment and deteriorate the climate, but the consequences of my actions are borne by everyone else in the world. I may also contribute to street congestion, exerting another negative externality onto others.

There may be "internalities" as when we fail to act in our own self-interest. One can even think of inequality as of a market failure, since there is no reason why a market would deliver the distribution of income that we would have dreamt of before knowing our place in society.

The correction of these market failures requires a strong state; one that is independent from lobbies, has integrity and applies the precepts of the common good. In my view, the modern state is a referee, not a player. The state should correct market failures (guarantee equal opportunities in health and education, implement redistribution, competition policy and regulation, environmental and consumer protection, etc).

People often said in the wake of the $2008 \mathrm{fi}$ nancial crisis that we do not need finance. That is a wrong idea. Finance is indispensable. It allows all sorts of economic agents- households, firms, states- to borrow and hedge themselves against various risks. Financial institutions also create saving products for these actors. The financial crisis of 2008 was a crisis of the state, a crisis of regulation. Lenient regulation and supervision created the wrong incentives. Weak regulation implies that some unscrupulous actors will take advantage of the loopholes and wrong incentives, exploit the system pitilessly. It is one thing to blame the financial industry for doing the wrong things, and yes, some people are not very honest and take advantage of these wrong incentives. However, the state should not create wrong incentives in the first place. Take financial bubbles, where politics were very much involved. In countries such as the US and Spain, politicians wanted people to own houses and apartments and create a construction boom; they pushed banks to lend to real estate construction companies and regulated leniently both mortgages and their securitization. The rest is history, as they say. For 
instance, there was a huge recession in Spain and the human suffering was tremendous.

Many people think of the market and the state as substitutes. However, they should be complementary, in the sense that the market occasionally needs some regulation to function well; and, conversely, the state needs incentives. When they both fail, we have to appeal to our social responsibility, as individuals and as corporations.

\section{PRECEPTS FOR GOOD PUBLIC POLICY}

That brings me to the public policy. The design of the state often does not match the economy of the $21^{\text {st }}$ century. Let us enunciate three principles for this design.

The first precept is to avoid hubris. The state should not try to do things that it cannot do because it does not have the information. For example, suppose that the state wants to reduce pollution. One possibility is to set a price for carbon, and let companies and households decide whether they want to pollute the environment or pay the carbon tax. That policy requires no information as to who is best placed to reduce pollution; the existence of a uniform carbon price ensures that those agents with the lowest abatement cost will actually abate, ensuring a reduction in pollution at minimum cost.

Same idea, if you want to use incentives in the labour market: Because the state does not know which employee is needed by a company and which is not, it is best advised to employ what in the US is called "experience rating". This policy consists in making the company internalize at least in part the cost that it imposes on the unemployment benefit scheme when a worker is laid off (which is distinct from severance pay, which corresponds to the internalization of externality on the employee). Here too, the state be humble; it must take into account that it often does not have the information required to efficiently control and direct each economic decision; instead it must align the interests of the firm with those of the broader society.

The second point is that our societies should sometimes resist the call for "political primacy". Political accountability is not adequate for all decisions. There are many instances of successful independent agencies. A case in point is competition policy. When in the past competition policy was executed by the ministry, the CEO of a powerful company that was threatened by an antitrust lawsuit would call the minister and ask for political interference in the case. Economic arguments were sometimes of little importance; it was more important to have been in school with, or be a friend of the minister. Since the 1980s, independent authorities are in charge of anti-trust policies in Europe; and, although I don't agree with each and every decision, much better anti-trust enforcement has occured. Another case in point is the legal system. In the Anglo-Saxon tradition, it has long been accepted that courts should be independent of the government; this independence is very important indeed, in order to protect minorities against the majority and to ensure that the powerful do not enjoy immunity from prosecution.

A final case in point is central bank independence. In many countries around the world, the rise of populism comes together with a call for making the central banks come under the thumb of the political power. In the name of "accountability". To give two examples among many, the current US President keeps criticising the Federal Reserve, and the Prime Minister of India has been fighting with the Reserve Bank of India, the central bank. Attacks on central bank independence are also fueled by central banks' large balance sheets. They have bought many bonds from various countries, usually their own; and, substituting for elected officials, who do not dare to do it, they take on some fiscal role by lending to various countries such as Greece. That may jeopardize the independence of the central bank.

We need independent central banks for at least two reasons. One is monetary policy. Independent central banks are better at confronting inflation. Before central banks became independent entities, there was often a strong inflation as the politicians wanted to get some stimulus just before the election ("pump priming”); they were concerned about being re-elected. Politicians usually want lower interest rates. The low-interest rate policy can be fine in certain circumstances, and indeed independent central bankers did the right thing after 2008 by lowering the interest rate. They thought that the financial system was too risky and they tried to keep the credit flowing to companies. However, this should be done for economic reasons and not for political reasons. We need independent central banks with talented people in the top jobs. Central banks are also engaged in the prudential supervision of banks. Independent central banks are better at maintaining capital standards. They also make mistakes, to be certain, but at least, they are protected from political will: politicians cannot impose a relaxation of capital standards, or favour their friends, or simply cause credits flowing into the economy. 
As I said earlier, blaming politicians for flawed policies will not get us very far. Sure, sometimes they deserve blame. While some are competent, honest and courageous, others are not. However it is very difficult to build institutions on the premise that politicians - or any economic agent for that matter will systematically put the common good ahead of their own self-interest. Like all of us, they respond to the incentives they face, in their case the desire to stay in power. So, for democracy to work, one has to build checks and balances inside and outside the government, from independent authorities to strong, unconnected media and political competition keeping the government on its toes. Another important counter-power in this era of fake news and bad reasoning is a good and critical education; we must train pupils and students so that when they are confronted with a fake fact or a flawed argument, they get the chance to detect it and understand that they are being manipulated. Otherwise, we, the citizens, get the policies we deserve.

\section{THE ECONOMIST'S MISSION}

Economists have sometimes had a bad press, especially since the financial crisis. Some of the criticism is warranted and some is not. There are pitfalls for the economics profession. Our judgment may be impaired by financial conflicts of interest, political friendships or ambitions for public recognition. Being on TV, on the radio, in newspapers is flattering. But it does not necessarily promote the common good.

We must also accept that we economists are not always good at communicating. In particular, we often fail to communicate what we are good at and bad at. We are better at analysing situations and drawing implications for policy than at predicting. I am currently worried about the potential for a new financial crisis. I can describe to you why, but if you ask me when it is going to come - in a month, or 5 years, or never at all - I will not be able to tell you. A bit like a doctor who will diagnose potential frailty and recommend remedies, but is completely unable to predict the timing; or a seismologist who cannot predict the date of occurrence of an earthquake. And we do not share enough our knowledge with the wider audience. The reason why I wrote The Economics for the Common Good was precisely to share knowledge with an audience wider than just experts. I have been talking to experts in business and governments for 30 years. But the wider public must also have access to expert knowledge for democracy to flourish.
We must also be humble. Sometimes, we have insufficient information about numbers; for example, in the onset of the financial crisis, most economists had insufficient knowledge of the magnitude of the exposure of banks to over-the-counter markets (OTC markets), and of the extent to which they shifted risk to the so-called conduits. We knew that such practices could be dangerous, but were mostly ignorant of their extent.

And then we must accept the fact that the economics, although it is a science, is not an exact science. Besides the facts that good data may be unavailable and that theories may oversimplify, there is also a specificity of the social sciences. Agents follow different and sometimes unpredictable behavioural patterns. For example, self-fulfilling phenomena (a bank run, a run on a currency) describe behaviors in which people engage only because others do as well. This makes it very difficult to predict when a crisis may happen.

The next thing I want to mention is when communicating, we must confront our audience's cognitive biases (biases to which we ourselves are exposed). Thus, Economics for the Common Good spends time explaining how these cognitive biases make communication of science, not only economics, difficult. There are many cognitive biases that we could discuss, but let me focus on two.

Motivated beliefs refer to the observation that we believe what we want to believe. We see what we want to see. We dream of a different world, where accidents or incidents would not happen to ourselves and our loved ones. This blissful ignorance has real consequences as we may forego a medical check-up or not put our safety belt when driving. But there is also some functionality in it. We live happier when avoiding unpleasant thoughts. If we thought about death all the time, for example, then we would not live a happy life.

In the economic realm, we dream of a world in which people were nicer and one would not have to force people to drive slowly or companies to stop polluting or to avoid taxes. We want to believe in green growth. Many politicians say they want to fight climate change, and that "by the way, if we are green, we are going to grow faster". If you have a critical mind, you may ask: "If we grow faster by being green, why do not we do it now?" Somehow the official discourse makes little sense. The truth is that if we want to be green, we have to accept a small reduction in purchasing power and it is entirely worth it. To save our planet, it is worth losing a bit of GDP. 
Similarly, people hope that the public debt will go away: somebody else will pay or there will be no crisis. Overall we believe what we want to believe and of course that makes the work of the economist harder, because the economists are the bearer of bad news: they convey news that many citizens do not want to hear. And by the way, populists - the left wing and the right wing - both play with our demand for rosy beliefs. They promote the vision of the economy free of difficult choices. But let's leave it to them.

The other point is that we as economists are trained to think globally, that is about the overall effects of a policy. Let me give you only one example for the sake of time. Think about rent control. In an expensive city, people with low income or middle income cannot afford their own housing. So policies that cap rental prices are popular. They are well-meaning because they try to help people with little money. The direct beneficiaries of this policy are people who are already renting a flat, and are geographically stable. However, under a rent control there will soon be a supply shortage - what has indeed happened in many cities in the world. In the longer term, apartements are no longer maintained and even "beneficiaries" end up with an apartment that is completely run down. And the future generations will no longer have access to decent apartments. We economists must think beyond beneficiaries and look at indirect victims.

Let me conclude. Contrary to a widespread feeling, economists can be more valuable now than they have ever been. For that, though, they must be lucid about the pitfalls of their science. And like experts more broadly, they must confront populism, which is rampant or dominant around the world. The populists are extremely good at playing on our frustrations and fears, and frustrations and fears there are: the global financial crisis, the euro crisis, unemployment, the slowdown of economic growth, growing debt, job-destroying technologies (AI, robots), climate change, migration and so on. Populists exploit these fears and frustrations to foster widespread hostility to immigrants, distrust of free trade and xenophobia. And of course, people with expert knowledge are dismissed. Yet we need experts. Not because experts are infallible, but because a democracy cannot function without respect for expert knowledge: Otherwise "anything goes”. We must prepare for the digital revolution and protect consumers and citizens. We must save our planet for our children; we must make sure that the financial system is safe, reduce inequality within and between countries, and at the same time maintain a high growth rate.

I am confident that generosity and intelligence will prevail against populism and nationalism. Students at the Financial University, please be assured that what you are studying today, your expert knowledge matters; keep retraining in the future, keep your critical mind, so in your work life and as a citizen, you will keep using the correct analysis and expressing the right argument. And above all, never lose track of the common good.

\section{ABOUT THE AUTHOR}

Jean Tirole - 2014 Nobel Memorial Prize in Economic Sciences winner, PhD in Economics, Honorary Chairman Toulouse School of Economics, Toulouse, France jean.tirole@tse-fr.eu

\section{ИНФОРМАЦИЯ ОБ АВТОРЕ}

Жан Тироль - лауреат Нобелевской премии 2014 г., доктор экономических наук, президент Тулузской школы экономики, Тулуза, Франция jean.tirole@tse-fr.eu

The article was received on 27.11.2018; accepted for publication on 14.01.2019. The author read and approved the final version of the manuscript. Статья поступила 27.11.2018; принята к публикации 14.01.2019. Автор прочитал и одобрил окончательный вариант рукописи. 